\title{
Diversity and Mefenoxam Sensitivity of Phytophthora spp. Associated with the Ornamental Horticulture Industry in the Southeastern United States
}

H. A. Olson, Hampton Roads Agricultural Research and Extension Center, Virginia Polytechnic Institute and State University, Virginia Beach 23455; S. N. Jeffers, School of Agricultural, Forest, and Environmental Sciences, Clemson University, Clemson, SC 29634; K. L. Ivors, Mountain Horticultural Crops Research and Extension Center, North Carolina State University, Mills River 28759; K. C. Steddom, Texas AgriLife Research and Extension Center, Texas A\&M University, Overton 75684; J. L. Williams-Woodward, Department of Plant Pathology, University of Georgia, Athens 30602; M. T. Mmbaga, Otis Floyd Nursery Research Center, Tennessee State University, McMinnville 37110; D. M. Benson, Department of Plant Pathology, North Carolina State University, Raleigh 27695; and C. X. Hong, Hampton Roads Agricultural Research and Extension Center, Virginia Polytechnic Institute and State University, Virginia Beach 23455

\begin{abstract}
Olson, H. A., Jeffers, S. N., Ivors, K. L., Steddom, K. C., Williams-Woodward, J. L., Mmbaga, M. T., Benson, D. M., and Hong, C. X. 2013. Diversity and mefenoxam sensitivity of Phytophthora spp. associated with the ornamental horticulture industry in the southeastern United States. Plant Dis. 97:86-92.

Phytophthora isolates associated with ornamental plants or recovered from irrigation water in six states in the southeastern United States (Georgia, North Carolina, South Carolina, Tennessee, Texas, and Virginia) were identified and screened for sensitivity to mefenoxam. Isolates from forest and suburban streams in Georgia and Virginia were included for comparison. A new in vitro assay, utilizing 48-well tissue culture plates, was used to screen for mefenoxam sensitivity; this assay allowed high throughput of isolates and used less material than the traditional petri plate assay. In total, 1,483 Phytophthora isolates were evaluated, and 27 species were identified with Phytophthora nicotianae, $P$. hydropathica, and $P$. gonapodyides, the most abundant species

associated with plants, irrigation water, and streams, respectively. Only $6 \%$ of isolates associated with plants and 9\% from irrigation water were insensitive to mefenoxam at $100 \mu \mathrm{g}$ a.i./ml. Approximately $78 \%$ of insensitive isolates associated with plants were $P$. nicotianae, and most of these $(67 \%)$ came from herbaceous annual plants. Most of the insensitive isolates recovered from irrigation water were $P$. gonapodyides, P. hydropathica, P. megasperma, and P. pini, and $83 \%$ of the insensitive isolates from streams were $P$. gonapodyides. Overall, this study suggests that mefenoxam should continue to be a valuable tool in the management of Phytophthora diseases affecting ornamental plants in the southeastern United States.
\end{abstract}

Floriculture and nursery crops account for approximately $\$ 17$ billion in sales in the United States (31). Within the southeastern region of the United States, the ornamental horticulture industry is ranked among the top five agricultural commodities in Georgia, North Carolina, South Carolina, Tennessee, Texas, and Virginia and, together, these states account for over $20 \%$ of the U.S. value for greenhouse and nursery crops (38-43). Phytophthora root rot, crown rot, and foliage blight are well-established diseases in the ornamental plant industry, and management of these diseases is challenging (9). Environmental conditions in greenhouses and at nurseries are often favorable for the growth and sporulation of many species of Phytophthora. An increasing number of facilities utilize recycled irrigation water that can disperse inoculum of these pathogens throughout the facility and move it off site. In addition, host plants are available for infection continually because ornamental plants are produced year round (9).

In the past 10 years, surveys of nurseries and greenhouses for species of Phytophthora have been conducted in several states in the United States $(10,23,26,27,29,32,37,45,47,51,52)$. These

\section{Corresponding author: H. A. Olson, E-mail: heather.a.olson@gmail.com}

Current address of H. A. Olson: Seminis Vegetable Seeds, Monsanto Company, Warner Robins, GA 31088.

* The e-Xtra logo stands for "electronic extra" and indicates that a supplementary figure and a supplementary table are included in the online edition.

Accepted for publication 25 July 2012.

http://dx.doi.org/10.1094/PDIS-04-12-0348-RE

(C) 2013 The American Phytopathological Society statewide surveys have been extremely important in establishing baseline information on the impact of Phytophthora spp. on production of ornamental plants, including the species of Phytophthora present and the ornamental plant species affected. However, the ornamental horticulture industry is extremely integrated, and plants frequently move across state lines (9). Because of this, Phytophthora spp. can be moved with infested plant material throughout a region or even across the country, as exemplified by Phytophthora ramorum - the causal agent of sudden oak death (SOD) in California (9).

Mefenoxam (metalaxyl-M), the more active enantiomer of metalaxyl, is the active ingredient (a.i.) of a partially systemic fungicide frequently used in the management of diseases caused by various Oomycetes-including species of Phytophthora. In a 2006 survey of six states, approximately $20 \%$ of nursery and floriculture production facilities reported applying a total of $37,000 \mathrm{~kg}$ of mefenoxam (50). Of particular concern are recent reports of mefenoxam-insensitive isolates of Phytophthora spp. from ornamental plants in North Carolina $(29,37)$ and Virginia (26), suggesting that mefenoxam insensitivity is becoming more common in the ornamental plant industry. Recycled irrigation water potentially could disperse mefenoxam-insensitive isolates of Phytophthora throughout a production facility, which could result in reduced or complete loss of efficacy by this important fungicide.

Over the past 10 years, several ornamental plant pathology laboratories in the southeastern United States have accumulated collections of Phytophthora isolates through surveys of ornamental plant production facilities, samples sent to plant disease clinics, and other studies. The objective of this study was to utilize these collections to determine the prevalence of mefenoxam insensitivity among isolates of Phytophthora spp. associated with plants and irrigation water in the ornamental horticulture industry in the 
southeastern United States and to discuss implications for disease management with mefenoxam.

\section{Materials and Methods}

Identification of species of Phytophthora. Phytophthora isolates associated with ornamental plants (i.e., isolated directly from plant tissue or recovered from potting medium around diseased plant roots) in Georgia, North Carolina, South Carolina, Tennessee, Texas, and Virginia and from irrigation water in Georgia, North Carolina, Tennessee, Texas, and Virginia (Table 1) were identified with standard morphological and molecular methods, including colony morphology, production of sporangia and oospores, singlestrand-conformational polymorphism (SSCP) of the ribosomal DNA (rDNA), restriction fragment length polymorphisms (RFLP) of the internal transcribed spacer (ITS) region of the rDNA, and DNA sequencing of the ITS region $(8,12,15)$. In addition, Phytophthora isolates from forest and suburban streams collected during SOD surveys in Georgia (68 isolates) and Virginia (239 isolates) were included for comparison. All isolates are maintained in permanent culture collections at one or more of the collaborating universities.

Mefenoxam sensitivity assay. Phytophthora isolates were tested for sensitivity to mefenoxam at $100 \mu \mathrm{g}$ a.i./ml by evaluating mycelium growth on medium amended with mefenoxam. To establish actively growing cultures, isolates were transferred to $60-\mathrm{mm}$ petri plates containing $5 \mathrm{ml}$ of $10 \%$ clarified V8 juice agar (CV8A; $100 \mathrm{ml}$ of buffered and clarified V8 juice, $15 \mathrm{~g}$ of Bacto agar [Becton, Dickinson, and Co.], and $900 \mathrm{ml}$ of deionized or distilled water) (13), and cultures were incubated for 3 to 4 days at $25^{\circ} \mathrm{C}$ in the dark. Mefenoxam sensitivity was evaluated with an assay developed by S. N. Jeffers at Clemson University and utilized 48well tissue culture plates (VWR International, Inc.) with $0.5 \mathrm{ml}$ of agar medium added to each well. For each plate, wells in rows A to C contained 5\% CV8A $(50 \mathrm{ml}$ of buffered and clarified V8 juice, $15 \mathrm{~g}$ of Bacto agar, and $950 \mathrm{ml}$ of deionized or distilled water) amended with mefenoxam (Subdue MAXX; Syngenta Crop Protection) at $100 \mu \mathrm{g}$ a.i./ml, and wells in rows D to F contained nonamended 5\% CV8A. One column of a plate was used for each isolate; therefore, eight isolates were screened on a single plate, with three replicate wells of amended and three replicate wells of nonamended media per isolate. Agar plugs (1 $\mathrm{mm}$ in diameter) were cut from a culture approximately 3 to $4 \mathrm{~mm}$ from the colony edge with the tip of a sterilized glass disposable Pasteur pipet (Fisher Scientific), and a single plug was transferred to the agar surface in each well in a column. The plates were covered and placed in the dark for 3 to 4 days at $25^{\circ} \mathrm{C}$. All wells then were evaluated for growth on a 0 -to- 5 scale, where $0=$ no growth; $1=$ hyphae visible only microscopically $(\times 10$ to 70$)$, with a few hyphae growing from the plug; 2 = hyphae visible only microscopically, with uniform growth around the plug; $3=$ mycelium just visible macroscopically, with uniform growth around plug; 4 = mycelium visible macroscopically but growth less than growth in nonamended wells; and $5=$ mycelium visible macroscopically and growth equal to that in nonamended wells. A pictorial guide was distributed to each participating lab to minimize variation in scoring among labs (Supplementary Figure S1). In addition, all labs used the same standard mefenoxam-insensitive isolate and mefenoxam-sensitive isolate of $P$. nicotianae as controls in each independent assay. If the control isolates did not respond to mefenoxam as expected, the assay results were rejected. Each isolate was assayed twice to confirm mefenoxam sensitivity, and sensitivity scores from the two trials were averaged. Isolates of Phytophthora spp. with a mean score of less than 3 were rated as sensitive, 3 to less than 4 were rated as intermediate, and 4 to 5 were rated as insensitive. Isolates from Georgia, Tennessee, and Virginia were evaluated by the Hong lab; isolates from North Carolina, South Carolina, and Texas were evaluated by labs in their respective states. In addition, isolates of $P$. ramorum were evaluated separately in a locked $20^{\circ} \mathrm{C}$ incubator in a restricted-access laboratory at the Hampton Roads Research and Extension Center,
Virginia Beach, VA under United States Department of Agriculture (USDA) Animal and Plant Health Inspection Service Permit Number P526P-10-00732. All USDA biosafety protocols were followed.

Comparison of mefenoxam sensitivity assays. To ensure that results from the 48-well culture plate assay were directly comparable with results from the standard petri plate assay, 43 isolates of $P$. nicotianae from ornamental plants and irrigation water (12 from North Carolina and 31 from Virginia) were screened with the 48well method, and these results were compared with those from the petri plate assay that were published previously $(24,26,36,37)$.

\section{Results}

Diversity of Phytophthora spp. In total, 488 isolates of Phytophthora associated with ornamental plants in six states (Georgia, North Carolina, South Carolina, Tennessee, Texas, and Virginia) were evaluated, and 464 of these isolates were identified as 19 different species (Table 2). P. nicotianae, representing $27 \%$ of the isolates associated with ornamental plants (Fig. 1), was the only species recovered in all six states (Table 2). Other significant species associated with ornamental plants included $P$. cinnamomi (23\%, four states), P. ramorum (13\%, one state), P. palmivora (11\%, three states), P. pini (5\%, four states), P. citrophthora (4\%, five states), and P. drechsleri (3\%, three states) (Fig. 1; Table 2). Other species of Phytophthora represented less than $2 \%$ of the isolates that were associated with ornamental plants.

Of the 690 isolates collected from irrigation water in five states (Georgia, North Carolina, Tennessee, Texas, and Virginia), 499 isolates were identified as 23 species of Phytophthora (Table 3). P. hydropathica was the predominant species collected from irrigation water, representing $18 \%$ of the isolates (Fig. 1), and this was the only species recovered from irrigation water in all five states (Table 4). P. citrophthora (13\%, three states), P. gonapodyides (10\%, one state), P. irrigata (5\%, two states), P. pini (5\%, two states), $P$. tropicalis (5\%, three states), P. megasperma (4\%, two states), and $P$. undulata (3\%, two states) also were collected from irrigation water (Table 3; Fig. 1). Other species represented less than $2 \%$ of the isolates recovered from irrigation water.

Of the isolates collected from streams in Georgia and Virginia, 229 of 305 isolates were identified as 15 distinct species of Phytophthora (Table 4). Only P. gonapodyides, $P$. hydropathica, and $P$. pini were recovered from streams in both states (Table 4) and, together, represented $56 \%$ of the isolates recovered from streams. In total, 291 isolates (24 from ornamental plants, 191 from irrigation water, and 76 from streams) could not be assigned to a documented species and, therefore, are reported as Phytophthora spp. (Tables 2-4).

Mefenoxam sensitivity. In total, 1,483 isolates of Phytophthora were screened for sensitivity to mefenoxam at $100 \mu \mathrm{g}$ a.i./ml (Tables 2-4). Overall, only 102 isolates (7\%) were insensitive to mefenoxam. Of the isolates associated with ornamental plants, $6 \%$ were insensitive to mefenoxam and $4 \%$ exhibited intermediate sensitivity (Table 2). In all, 21 of the 27 (78\%) mefenoxaminsensitive isolates belonged to P. nicotianae (Table 2), with $67 \%$ recovered from herbaceous annual plants (Fig. 2). Fisher's exact

Table 1. Numbers of Phytophthora isolates associated with ornamental plants and from irrigation water evaluated by researchers in six southeastern states

\begin{tabular}{lccc}
\hline State & Plants $^{\mathbf{a}}$ & Water & Total \\
\hline Georgia & 96 & 39 & 135 \\
North Carolina & 20 & 68 & 88 \\
South Carolina & 182 & 0 & 182 \\
Tennessee & 31 & 42 & 73 \\
Texas & 9 & 27 & 36 \\
Virginia & 150 & 514 & 664 \\
All states & 488 & 690 & 1,178 \\
\hline
\end{tabular}

a Isolates were recovered directly from plant tissue or baited from potting medium around the roots of diseased plants. 
test was significant $(P=0.0001)$ for a positive association between mefenoxam sensitivity and the type of ornamental plant (annual or perennial). The other six mefenoxam-insensitive isolates belonged to $P$. undulata (four isolates), $P$. palmivora (one isolate), and $P$. taxon 'Pgchlamydo' (one isolate) (Table 2).

Of the 690 isolates collected from irrigation water, $9 \%$ were insensitive to mefenoxam at $100 \mu \mathrm{g}$ a.i./ml. Of these, 10 isolates could not be identified, and the other 53 isolates belonged to eight species: $P$. drechsleri, $P$. gonapodyides, $P$. hydropathica, $P$. insolita, $P$. megasperma, $P$. nicotianae, $P$. taxon 'Pgchlamydo', and $P$. pini (Table 3 ). In addition, 53 isolates were intermediate in sensitivity to mefenoxam at $100 \mu \mathrm{g}$ a.i./ml (Table 3). Of the 305 isolates collected from streams in Georgia and Virginia, $4 \%$ were insensitive to mefenoxam, and these isolates belonged to only three species: $P$. gonapodyides (10 isolates), $P$. hydropathica (1 isolate), and $P$. plurivora (1 isolate) (Table 4). In total, 40 stream isolates were intermediate in sensitivity to mefenoxam, including 33 isolates in five known species (primarily P. gonapodyides and P. pini) and 7 isolates that were not identified (Table 4).

Comparison of mefenoxam sensitivity assays. The mefenoxam sensitivity ratings of 41 of the 43 isolates $(95.3 \%)$ of P. nicotianae evaluated with both the 48 -well and petri plate assays agreed (Supplementary Table S1). Two Virginia isolates, 18C5 and 30J6, had ratings that were not consistent between the two assays. Both isolates were intermediate in sensitivity to mefenoxam at $100 \mu \mathrm{g}$ a.i./ml with the petri plate method (growth less than $40 \%$ of that on nonamended medium) $(24,26)$; however, isolate $18 \mathrm{C} 5$ was rated as sensitive (mean score of 1.3) and isolate $30 \mathrm{~J} 6$ was rated as resistant (mean score of 5.0) in the 48-well method.

\section{Discussion}

In total, 27 documented species of Phytophthora were identified from the ornamental horticulture industry in six southeastern states (Georgia, North Carolina, South Carolina, Tennessee, Texas, and Virginia) in this study. Although the Phytophthora isolates examined primarily came from established collections maintained by the authors and did not come from surveys conducted specifically for this study, most of the predominant species associated with ornamental plants are well-established pathogens of ornamental crops $(10,23,26,27,29,32,37,45,47,51,52)$. The exception to this is $P$. pini, which represented $5 \%$ of the isolates associated with ornamental plants that we evaluated. Prior to this, the only published report of $P$. pini on ornamental plants was two isolates recovered from rhododendron (Rhododendron catawbiense; 18). However, P. pini recently was reinstated as a distinct species from a subgroup of the $P$. citricola complex (18); therefore, some previous reports of $P$. citricola on ornamental plants actually may be reports of $P$. pini. Although $P$. ramorum represented $13 \%$ of the isolates associated with ornamental plants that we evaluated, these numbers are inflated because the isolates from Georgia included numerous isolates of $P$. ramorum from the initial SOD traceforward surveys conducted in 2004. If these numbers are removed from the totals, then $P$. ramorum is not a species commonly found in the ornamental plant industry in the southeastern United States at this time.

Likewise, most of the predominant species of Phytophthora from irrigation water that we evaluated are known to occur in irrigation water at ornamental plant nurseries $(5,16,19,20,23)$. Interestingly, there was little overlap between the predominant species associated with ornamental plants and the predominant species present in irrigation water. For example, in this study, $P$. nicotianae comprised $27 \%$ of ornamental plant isolates but only $1 \%$ of the irrigation water isolates. Likewise, $P$. hydropathica was the most abundant species among isolates from irrigation water but only rarely was associated with ornamental plants. The exceptions to this were $P$. citrophthora and $P$. pini; these were the only two species that frequently were found on plants and in irrigation water. Similarly, only $P$. citrophthora and $P$. citricola were recovered from both nurseries and watersheds in a survey in eastern Tennessee (27). Four of the species of Phytophthora that were common in irrigation water in our study (namely, $P$. gonapodyides, $P$. hydropathica, $P$. irrigata, and $P$. pini) also were present in streams in Georgia and Virginia, suggesting that these species of Phytophthora are more adapted to aquatic habitats than to terrestrial habitats. Previously, others have suggested species of Phytophthora that occur commonly in streams may have an aquatic nature and be resident in water $(30,44)$. Stream surveys in the eastern United States $(27,30)$ and in Oregon and Alaska (44) recovered many of the same water-inhabiting species detected in streams in Georgia and Virginia.

Table 2. Mefenoxam sensitivity of Phytophthora isolates associated with ornamental plants in six southeastern states ${ }^{\mathrm{a}}$

\begin{tabular}{|c|c|c|c|c|c|}
\hline \multirow[b]{2}{*}{ Species } & \multirow[b]{2}{*}{ States of isolate origin ${ }^{c}$} & \multicolumn{4}{|c|}{ Mefenoxam sensitivity (number) ${ }^{b}$} \\
\hline & & Sensitive & Intermediate & Insensitive & Total \\
\hline Phytophthora cactorum & VA & 7 & 0 & 0 & 7 \\
\hline P. cambivora & $\mathrm{NC}$ & 1 & 0 & 0 & 1 \\
\hline P. capsici & $\mathrm{NC}$ & 0 & 1 & 0 & 1 \\
\hline P. cinnamomi & $\mathrm{NC}, \mathrm{SC}, \mathrm{TN}, \mathrm{VA}$ & 110 & 0 & 0 & 110 \\
\hline P. citricola & $\mathrm{SC}, \mathrm{TN}$ & 2 & 0 & 0 & 2 \\
\hline P. citrophthora & GA, NC, SC, TN, VA & 19 & 1 & 0 & 20 \\
\hline P. cryptogea & $\mathrm{SC}, \mathrm{TN}$ & 8 & 0 & 0 & 8 \\
\hline P. drechsleri & GA, SC, VA & 13 & 0 & 0 & 13 \\
\hline P. heveae & $\mathrm{NC}$ & 1 & 0 & 0 & 1 \\
\hline P. hydropathica & GA, NC, TN, VA & 8 & 1 & 0 & 9 \\
\hline P. megasperma & VA & 1 & 1 & 0 & 2 \\
\hline P. nicotianae & GA, NC, SC, TN, TX, VA & 108 & 3 & 21 & 132 \\
\hline P. palmivora & GA, SC, VA & 55 & 0 & 1 & 56 \\
\hline P. taxon 'Pgchlamydo' & $\mathrm{NC}$ & 0 & 0 & 1 & 1 \\
\hline P. pini & GA, NC, TN, VA & 20 & 4 & 0 & 24 \\
\hline P. plurivora & VA & 1 & 2 & 0 & 3 \\
\hline P. ramorum $^{\mathrm{d}}$ & GA & 65 & 0 & 0 & 65 \\
\hline P. tropicalis & $\mathrm{SC}, \mathrm{VA}$ & 2 & 2 & 0 & 4 \\
\hline P. undulata & $\mathrm{GA}, \mathrm{NC}$ & 0 & 1 & 4 & 5 \\
\hline Phytophthora spp..$^{\mathrm{e}}$ & GA, NC, TN, VA & 19 & 5 & 0 & 24 \\
\hline All species & $\ldots$ & 440 & 21 & 27 & 488 \\
\hline
\end{tabular}

a Isolates were recovered directly from plant tissue or baited from potting medium around the roots of diseased plants.

b Mefenoxam sensitivity was based on a 0-to-5 scale, where Sensitive $=$ score of $<3$, Intermediate $=$ score of 3 to $<4$, and Insensitive $=$ score of 4 to 5 .

${ }^{\mathrm{c}} \mathrm{GA}=$ Georgia, $\mathrm{NC}=$ North Carolina, $\mathrm{SC}=$ South Carolina, $\mathrm{TN}=$ Tennessee, $\mathrm{TX}=$ Texas, and VA = Virginia.

d Isolates of P. ramorum were collected as part of the 2004 APHIS nursery trace-forward survey for camellia and rhododendron where the Confirmed Nursery Protocol was followed.

e Isolates that could not be identified to species. 
Because of environmental concerns as well as water shortages, a greater emphasis has been put on reclaiming and reusing irrigation water in the ornamental plant industry (9), and it is thought that, once Phytophthora spp. are introduced into a nursery or greenhouse, propagules can be disseminated throughout the facility in contaminated recycled irrigation water (21). However, our study indicates that most species of Phytophthora that are significant plant pathogens were not frequently found in irrigation water. The causes and implications of this discrepancy are unclear at this point. Previously, isolates of $P$. hydropathica and $P$. irrigata from irrigation water were shown to be potential pathogens on azaleas (Rhododendron hybrids) in artificial inoculation tests (22) but, in our study, $P$. irrigata was not associated with plants and $P$. hydro-

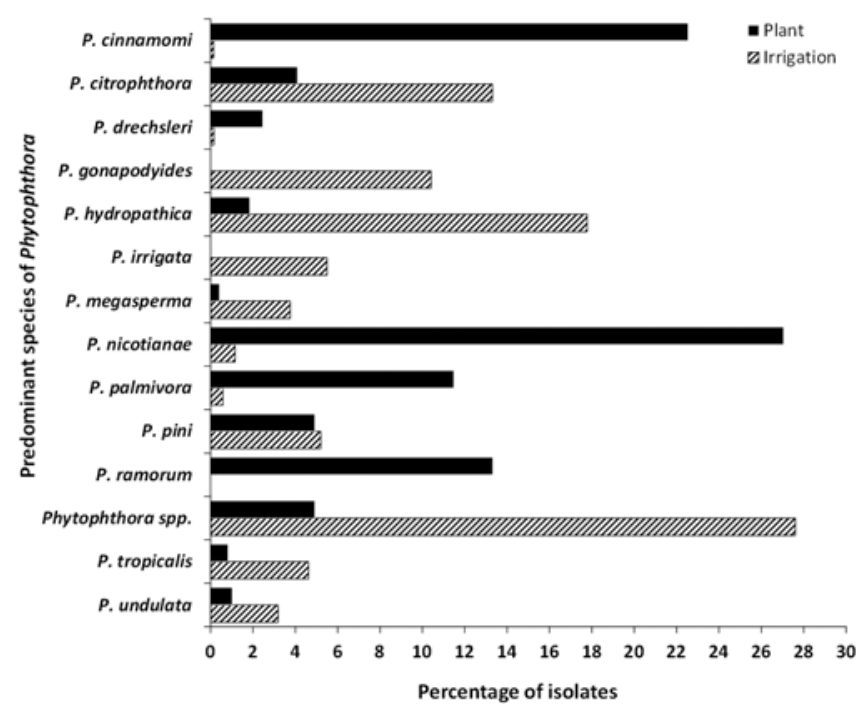

Fig. 1. Relative abundance of the predominant species of Phytophthora found associated with ornamental plants or present in irrigation water at ornamental production facilities in six southeastern states. Each species included represented at least $2 \%$ of the total number of isolates associated with ornamental plants or present in irrigation water. pathica was found only rarely associated with plants. Consequently, these two aquatic species do not appear to pose serious threats to the production of ornamental plants in the southeastern United States at this time.

Overall, insensitivity to mefenoxam (metalaxyl-M) was not widespread among species of Phytophthora associated with the ornamental horticulture industry in the southeastern United States; only $6 \%$ of isolates recovered from ornamental plants were insensitive to mefenoxam at $100 \mu \mathrm{g}$ a.i./ml. Only 4 of the 19 species of Phytophthora associated with ornamental plants had insensitive isolates, and only 1 species that occurs commonly on ornamental plants, $P$. nicotianae, had more than one or two insensitive isolates. Therefore, it appears that insensitivity to mefenoxam in the ornamental industry is not a major concern because most species have remained sensitive even 30 years after the introduction of metalaxyl to this industry.

P. nicotianae accounted for $78 \%$ of insensitive isolates associated with ornamental plants. In all, $67 \%$ of the mefenoxam-insensitive isolates of $P$. nicotianae were collected from annual plants; specifically, annual vinca (Catharanthus roseus), tropical hibiscus (Hibiscus hybrid), pansy (Viola $\times$ wittrockiana), and petunia (Petunia $\times$ hybrida). Since the initial report of metalaxyl insensitivity in $P$. nicotianae $(=P$. parasitica) from annual vinca by Ferrin and Kabashima in 1991 (14), mefenoxam insensitivity has been reported multiple times for isolates recovered from annual ornamental plants. Lamour et al. (32) recovered 15 mefenoxam-insensitive isolates of P. nicotianae from fuchsia (Fuchsia $\times$ hybrida), and Hwang and Benson (29) reported 56 mefenoxam-insensitive isolates from annual vinca and petunia. Similarly, 23 mefenoxaminsensitive isolates of $P$. nicotianae were collected from annual vinca and petunia in Virginia (26), and S. N. Jeffers found 15 insensitive isolates among 145 isolates of $P$. nicotianae recovered from ornamental plants, primarily annual vinca and petunia, in South Carolina between 1995 and 2001 (unpublished data). Most recently, Olson and Benson (37) reported that 56 isolates of $P$. nicotianae recovered from calibrachoa (Calibrachoa $\times$ hybrida), dusty miller (Senecio cineraria), fuchsia, and petunia in North Carolina greenhouses were insensitive to mefenoxam at $100 \mu \mathrm{g}$ a.i./ml. In our study, five of the mefenoxam-insensitive isolates of

Table 3. Mefenoxam sensitivity of Phytophthora isolates recovered from irrigation water in five southeastern states

\begin{tabular}{|c|c|c|c|c|c|}
\hline \multirow[b]{2}{*}{ Species } & \multirow[b]{2}{*}{ States of isolate origin ${ }^{b}$} & \multicolumn{4}{|c|}{ Mefenoxam sensitivity (number) $^{\mathbf{a}}$} \\
\hline & & Sensitive & Intermediate & Insensitive & Total \\
\hline Phytophthora aquimorbida & GA,VA & 8 & 0 & 0 & 8 \\
\hline P. cactorum & VA & 7 & 0 & 0 & 7 \\
\hline P. capsici & VA & 1 & 0 & 0 & 1 \\
\hline P. cinnamomi & $\mathrm{NC}$ & 1 & 0 & 0 & 1 \\
\hline P. citrophthora & $\mathrm{GA}, \mathrm{NC}, \mathrm{VA}$ & 92 & 0 & 0 & 92 \\
\hline P. cryptogea & $\mathrm{NC}$ & 1 & 0 & 0 & 1 \\
\hline P. drechsleri & VA & 0 & 0 & 1 & 1 \\
\hline P. gonapodyides & VA & 43 & 12 & 17 & 72 \\
\hline P. hydropathica & GA,NC,TN,TX,VA & 107 & 6 & 10 & 123 \\
\hline P. insolita & VA & 9 & 1 & 1 & 11 \\
\hline P. inundata & VA & 1 & 0 & 0 & 1 \\
\hline$P$. irrigata & TX,VA & 37 & 1 & 0 & 38 \\
\hline P. megasperma & $\mathrm{TN}, \mathrm{VA}$ & 8 & 4 & 14 & 26 \\
\hline P. nicotianae & GA,NC,TX,VA & 7 & 0 & 1 & 8 \\
\hline P. palmivora & $\mathrm{NC}, \mathrm{VA}$ & 4 & 0 & 0 & 4 \\
\hline P. taxon 'Pgchlamydo' & $\mathrm{NC}$ & 7 & 0 & 1 & 8 \\
\hline P. pini & $\mathrm{NC}, \mathrm{VA}$ & 24 & 4 & 8 & 36 \\
\hline P. plurivora & VA & 1 & 0 & 0 & 1 \\
\hline P. polonica & $\mathrm{NC}, \mathrm{TN}, \mathrm{VA}$ & 4 & 0 & 0 & 4 \\
\hline P. pseudosyringae & VA & 1 & 0 & 0 & 1 \\
\hline$P$. syringae & VA & 1 & 0 & 0 & 1 \\
\hline P. tropicalis & $\mathrm{GA}, \mathrm{NC}, \mathrm{VA}$ & 19 & 13 & 0 & 32 \\
\hline P. undulata & GA,TX & 19 & 3 & 0 & 22 \\
\hline Phytophthora spp. ${ }^{\mathrm{c}}$ & GA,NC,TN,VA & 172 & 9 & 10 & 191 \\
\hline All species & $\ldots$ & 574 & 53 & 63 & 690 \\
\hline
\end{tabular}

${ }^{\text {a }}$ Mefenoxam sensitivity was based on a 0 -to- 5 scale, where Sensitive $=$ score of $<3$, Intermediate $=$ score of 3 to $<4$, and Insensitive $=$ score of 4 to 5 .

${ }^{\mathrm{b}} \mathrm{GA}=$ Georgia, $\mathrm{NC}=$ North Carolina, $\mathrm{TN}=$ Tennessee, $\mathrm{TX}=$ Texas, and VA = Virginia .

${ }^{c}$ Isolates that could not be identified to species. 
P. nicotianae from perennial plants were isolated from two production locations in Virginia which also produce annual plants adjacent to perennial plants. It is conceivable that the mefenoxaminsensitive isolates could have been moved from the annual plants to the perennial plants. Most perennial crops are present at a production facility for multiple years and may only receive one or two applications of mefenoxam in a year. In contrast, multiple crops of annual ornamental plants are produced at a production facility in a single year, with each crop having the potential to receive one or more applications of mefenoxam. Therefore, propagules of Phytophthora spp. infecting these annual crops could be exposed to more applications of mefenoxam in a single year, which could encourage selection of mefenoxam-insensitive genotypes.

Interestingly, 9\% of Phytophthora isolates recovered from irrigation water were insensitive to mefenoxam, and there was very little overlap between species recovered from ornamental plants that exhibited insensitivity and species from irrigation water with insensitive isolates. Little information is available about the mefenoxam sensitivity of Phytophthora spp. commonly found in irrigation water and, to our knowledge, this is the first large-scale evaluation of isolates of Phytophthora spp. from irrigation water in the ornamental plant industry. Species found in irrigation systems potentially could be exposed to noninhibitory concentrations of mefenoxam because mefenoxam is highly soluble in water (49). Prolonged exposure in this manner could allow for selection of insensitive genotypes.

Insensitivity to mefenoxam was rare among isolates of Phytophthora spp. recovered from streams in Georgia and Virginia. The exception to this was $P$. gonapodyides. Approximately $11 \%$ of the isolates of this species from streams were insensitive to mefenoxam, and $24 \%$ of the isolates from irrigation water were insensitive to mefenoxam in this study. Interestingly, 54\% of isolates of $P$. megasperma, a species closely related to $P$. gonapodyides (4), from irrigation water also were insensitive to mefenoxam. Hunger et al. (28) found isolates of P. megasperma sensu lato collected prior to the release of metalaxyl were naturally insensitive to this fungicide at $10 \mu \mathrm{g} / \mathrm{ml}$ while sensitive isolates were inhibited completely with $1 \mu \mathrm{g} / \mathrm{ml}$; however, some of those isolates now may be regarded as separate species because $P$. megasperma has undergone taxonomic revision since the article by Hunger et al. was published (17). Similarly, isolates of $P$. citricola collected prior to the release of metalaxyl, including several from ornamental plants, exhibited a wide range of sensitivity to met-

Table 4. Mefenoxam sensitivity of Phytophthora isolates recovered from streams in Georgia and Virginia

\begin{tabular}{llrrrr}
\hline & & \multicolumn{4}{c}{$\begin{array}{c}\text { Mefenoxam sensitivity } \\
\text { (number) }\end{array}$} \\
\cline { 3 - 6 } Species & Origin $^{\mathbf{b}}$ & Sen & Int & Ins & Total \\
\hline Phytophthora cactorum & VA & 3 & 0 & 0 & 3 \\
$P$. cambivora & VA & 2 & 1 & 0 & 3 \\
$P$. cinnamomi & VA & 1 & 0 & 0 & 1 \\
P. citrophthora & VA & 2 & 0 & 0 & 2 \\
$P$. cryptogea & VA & 1 & 0 & 0 & 1 \\
$P$. gonapodyides & GA, VA & 60 & 19 & 10 & 89 \\
$P$. hydropathica & GA, VA & 31 & 1 & 1 & 33 \\
$P$. insolita & VA & 2 & 0 & 0 & 2 \\
$P$. irrigata & VA & 24 & 0 & 0 & 24 \\
$P$. megasperma & VA & 2 & 0 & 0 & 2 \\
$P$. pini & GA, VA & 39 & 11 & 0 & 50 \\
$P$. plurivora & VA & 11 & 1 & 1 & 13 \\
$P$. pseudosyringae & VA & 3 & 0 & 0 & 3 \\
$P$. tropicalis & GA & 1 & 0 & 0 & 1 \\
$P$. undulata & GA & 2 & 0 & 0 & 2 \\
Phytophthora spp. & GA, VA & 69 & 7 & 0 & 76 \\
All species & .. & 253 & 40 & 12 & 305 \\
\hline
\end{tabular}

a Mefenoxam sensitivity was based on a 0 -to- 5 scale, where Sen $=$ sensitive (score of $<3$ ), Int $=$ intermediate ( score of 3 to $<4$ ), and Ins $=$ insensitive (score of 4 to 5).

b States of isolate origin: GA $=$ Georgia and VA $=$ Virginia . alaxyl, with the least sensitive isolate having a $90 \%$ effective dose of $192.4 \mu \mathrm{g}$ a.i./ml (7). Mefenoxam-insensitive isolates of $P$. citricola have been recovered previously from ornamental plants $(10,14,27)$. In contrast to these species, $P$. cinnamomi, a species for which mefenoxam insensitivity has not been reported $(1,2,11,25,46)$, exhibited very little variation in sensitivity and was fully sensitive in our study and when isolates recovered prior to the release of metalaxyl were examined (7). Together, this suggests that some species of Phytophthora have a relatively high population of genotypes naturally tolerant to mefenoxam, and that repeated application of mefenoxam selected for these naturally tolerant genotypes and allowed them to proliferate. Stack and Millar (48) demonstrated selection of isolates naturally tolerant to mefenoxam by placing zoospores of $P$. medicaginis $(=P$. megasperma f. sp. medicaginis) on agar medium amended with the fungicide at various concentrations.

Traditionally, mycelium growth on mefenoxam-amended medium in petri plates has been used for screening isolates of Phytophthora spp. for sensitivity to mefenoxam (1). Although this assay is very reliable, it is cumbersome and expensive for screening large numbers of isolates. The 48-well culture plate assay developed by S. N. Jeffers at Clemson University and used here allowed consistent screening of large numbers of isolates with a minimum amount of materials. Results from the 48-well assay were found to be directly comparable with results from the petri plate assay for all but two of the isolates of $P$. nicotianae that were evaluated. The two isolates that disagreed were rated as intermediate with the petri plate assay but sensitive and insensitive by the 48-well assay, suggesting that the relationship between the intermediate category from the petri plate assay used by $\mathrm{Hu}$ et al. (26) and ratings from the 48-well plate assay may need to be evaluated more closely in the future. Alternatively, these two isolates may need to be re-tested with the petri plate method to verify their intermediate sensitivities.

Although some studies have used different concentrations of mefenoxam, including mefenoxam at 1,5 , and $10 \mu \mathrm{g}$ a.i./ml $(6,28,29,37)$, the biological significance of insensitivity at these low concentrations is unclear. During development of the assay protocol, mefenoxam at $100 \mu \mathrm{g}$ a.i./ml was selected because a relatively clear separation of sensitivity categories was achieved for isolates from a variety of species ( $\mathrm{S}$. N. Jeffers, personal communication). Similarly, Lamour and Hausbeck $(33,34)$ found that mefenoxam at $100 \mu \mathrm{g}$ a.i./ml divided populations of $P$. capsici into a clear trimodal distribution, with sensitive, intermediate, and

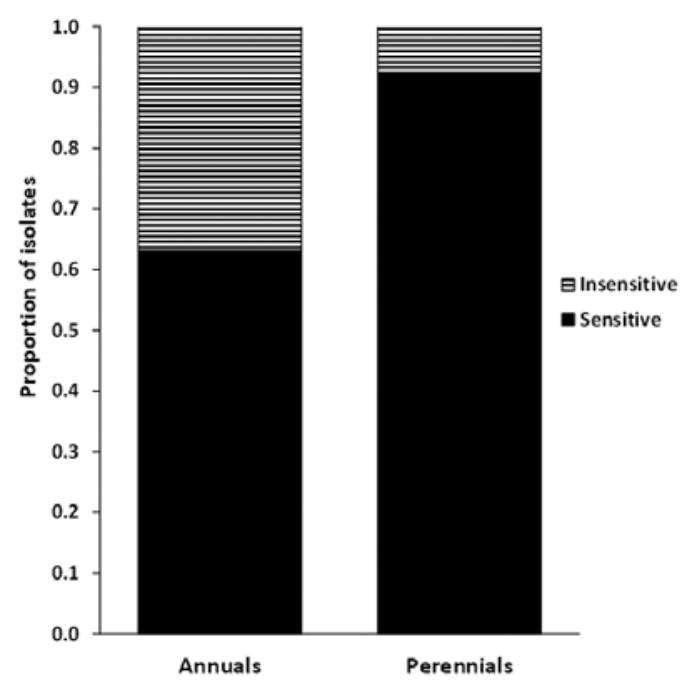

Fig. 2. Proportions of isolates of Phytophthora nicotianae from annual and perennial (including both woody and herbaceous) ornamental plants that were sensitive or insensitive to mefenoxam at $100 \mu \mathrm{g}$ a.i./ml in an in vitro assay. There was a significant $(P=0.0001)$ association between mefenoxam sensitivity and type of ornamental plant (annual or perennial) based on Fisher's exact test. 
insensitive isolates. More importantly, insensitivity of isolates of Phytophthora spp. to mefenoxam at $100 \mu \mathrm{g}$ a.i./ml in culture appears to be representative of insensitivity on plants treated with mefenoxam. In a separate study, mefenoxam failed to manage Phytophthora foliage blight on annual vinca plants and crown rot on petunia plants that were inoculated with isolates of $P$. nicotianae insensitive to mefenoxam at $100 \mu \mathrm{g}$ a.i./ml but it was effective at managing disease on petunia plants inoculated with a mefenoxam-sensitive isolate (H. A. Olson and C.X. Hong, unpublished). Likewise, in a study by $\mathrm{Hu}$ et al. (26), mefenoxam did not manage disease on geranium plants inoculated with isolates of $P$. nicotianae insensitive to mefenoxam at $100 \mu \mathrm{g}$ a.i. $/ \mathrm{ml}$. Ineffective management with mefenoxam has been observed with other species of Phytophthora as well. Lamour and Hausbeck (35) found that isolates of $P$. capsici insensitive to mefenoxam at $100 \mu \mathrm{g}$ a.i./ml caused disease in squash plants treated with mefenoxam at the label rate and three times the label rate. Similarly, Benson and Parker (3) reported $100 \%$ mortality of gerbera daisies treated with mefenoxam and inoculated with mefenoxam-insensitive isolates of P. drechsleri. While complete insensitivity at $100 \mu \mathrm{g}$ a.i./ml in vitro appears to be representative of mefenoxam insensitivity in plants, it is unknown what an intermediate response to mefenoxam in vitro corresponds to on plants. Additional research is needed on the ability of isolates with intermediate sensitivity in vitro to cause disease on plants treated with mefenoxam.

In summary, the diversity of Phytophthora spp. in the ornamental horticulture industry is high, which is not surprising considering the number of different plant species produced as ornamental crops. Whereas the overall diversity is high, only a few species of Phytophthora-particularly P. cinnamomi, P. citrophthora, P. nicotianae, and $P$. palmivora - appear to be the primary ones attacking ornamental plants in the southeastern United States. The difference in the predominant species associated with ornamental plants and those detected in irrigation water is somewhat surprising, and this supports the idea that some species of Phytophthora may be terrestrial inhabitants while others are aquatic inhabitants $(30,44)$. More importantly, most species of Phytophthora recovered from ornamental plants are sensitive to mefenoxam, except isolates of $P$. nicotianae recovered from annual plants. Consequently, this study suggests that mefenoxam should continue to be a valuable tool in the management of diseases caused by Phytophthora spp. on ornamental crops in the southeastern United States; in most cases, mefenoxam should manage Phytophthora root rot, crown rot, and foliage blight on these plants if applied at the rates and following the directions on the product label. Growers will continue to face challenges in the management of Phytophthora diseases and should not rely on mefenoxam as the only fungicide for these important diseases. In particular, our results should encourage growers to focus on best management practices and to target more robust fungicide rotation schemes when treating annual plants for diseases caused by species of Phytophthora.

\section{Acknowledgments}

Funding for this research came, in part, from the USDA National Institute of Food and Agriculture, Southern Region Integrated Pest Management Special Grants Program (agreement number 2010-34103-20990) and Syngenta Crop Protection, Greensboro, NC. We thank L. Lacey (North Carolina State University), L. Luszcz (Clemson University), and P. Richardson (Virginia Polytechnic Institute and State University) for providing technical assistance.

\section{Literature Cited}

1. Benson, D. M. 1979. Efficacy and in vitro activity of two systemic acylalanines and ethazole for control of Phytophthora cinnamomi root rot of azaleas. Phytopathology 69:174-178.

2. Benson, D. M., and Grand, L. F. 2000. Incidence of Phytophthora root rot of Fraser fir in North Carolina and sensitivity of isolates of Phytophthora cinnamomi to metalaxyl. Plant Dis. 84:661-664.

3. Benson, D. M., and Parker, K. C. 2009. Efficacy of registered and unregistered fungicides for control of Phytophthora drechsleri on Transvaal daisy. Plant Dis. Man. Rep. Online publication. 4:OT004.doi:10.1094/PDMR04

4. Blair, J. E., Coffey, M. D., Park, S.-Y., Geiser, D. M., and Kang, S. 2008. A multi-locus phylogeny for Phytophthora utilizing markers derived from complete genome sequences. Fungal Genet. Biol. 45:266-277.
5. Bush, E. A., Stromberg, E. L., Hong, C. X., Richardson, P. A., and Kong, P. 2006. Illustration of key morphological characteristics of Phytophthora species identified in Virginia nursery irrigation water. Plant Health Progress. Online publication. doi:10.1094/PHP-2006-0621-01-RS

6. Coffey, M. D., and Bower, L. A. 1984. In vitro variability among isolates of six Phytophthora species in response to metalaxyl. Phytopathology 74:502506.

7. Coffey, M. D., Klure, L. J., and Bower, L. A. 1984. Variabilty in sensitivity to metalaxyl of isolates of Phytophthora cinnamomi and Phytophthora citricola. Phytopathology 74:417-422.

8. Cooke, D. E. L., Drenth, A., Duncan, J. M., Wagels, G., and Brasier, C. M. 2000. A molecular phylogeny of Phytophthora and related Oomycetes. Fungal Genet. Biol. 30:17-32.

9. Daughtrey, M. L., and Benson, D. M. 2005. Principles of plant health management for ornamental plants. Annu. Rev. Phytopathol. 43:141-169.

10. Donahoo, R. S., and Lamour, K. H. 2008. Characterization of Phytophthora species from leaves of nursery woody ornamentals in Tennessee. Hortscience 43:1833-1837.

11. Duan, C. H., Riley, M. B., and Jeffers, S. N. 2008. Characterization of Phytophthora cinnamomi population from ornamental plants in South Carolina, USA. Arch. Phytopathol. Plant Prot. 41:14-30.

12. Erwin, D. C., and Ribeiro, O. K. 1996. Phytophthora Diseases Worldwide American Phytopathological Society, St. Paul, MN.

13. Ferguson, A. J., and Jeffers, S. N. 1999. Detecting multiple species of Phytophthora in container mixes from ornamental crop nurseries. Plant Dis 83:1129-1136.

14. Ferrin, D. M., and Kabashima, J. N. 1991. In vitro insensitivity to metalaxyl of isolates of Phytophthora citricola and P. parasitica from ornamental hosts in southern California. Plant Dis. 75:1041-1044.

15. Gallegly, M. E., and Hong, C. X. 2008. Phytophthora: Identifying Species by Morphology, and DNA Fingerprints. American Phytopathological Society, St. Paul, MN

16. Ghimire, S. R., Richardson, P. A., Kong, P., Hu, J. H., Lea-Cox, J. D., Ross, D. S., Moorman, G. W., and Hong, C. X. 2011. Distribution and diversity of Phytophthora species in nursery irrigation reservoir adopting water recycling system during winter months. J. Phytopathol. 159:713-719.

17. Hansen, E. M., Wilcox, W. F., Reeser, P. W., and Sutton, W. 2009. Phytophthora rosacearum and $P$. sansomeana, new species segregated from the Phytophthora megasperma "complex". Mycologia 101:129-135.

18. Hong, C. X., Gallegly, M. E., Richardson, P. A., and Kong, P. 2011. Phytophthora pini Leonian resurrected to distinct species status. Mycologia 103:351-360

19. Hong, C. X., Gallegly, M. E., Richardson, P. A., Kong, P., and Moorman, G. W. 2008. Phytophthora irrigata, a new species isolated from irrigation reservoirs and rivers in Eastern United States of America. FEMS Microbiol. Lett. 285:203-211.

20. Hong, C. X., Gallegly, M. E., Richardson, P. A., Kong, P., Moorman, G. W., Lea-Cox, J. D., and Ross, D. S. 2010. Phytophthora hydropathica, a new pathogen identified from irrigation water, Rhododendron catawbiense, and Kalmia latifolia. Plant Pathol. 59:913-921.

21. Hong, C. X., and Moorman, G. W. 2005. Plant pathogens in irrigation water: challenges and opportunities. Crit. Rev. Plant Sci. 24:189-208.

22. Hong, C. X., Richardson, P. A., and Kong, P. 2008. Pathogenicity to ornamental plants of some existing species and new taxa of Phytophthora from irrigation water. Plant Dis. 92:1201-1207.

23. Hong, C. X., Richardson, P. A., Kong, P., Jeffers, S. N., and Oak, S. W. 2006. Phytophthora tropicalis isolated from diseased leaves of Pieris japonica and Rhododendron catawbiense and found in irrigation water and soil in Virginia. Plant Dis. 90:525-525.

24. Hu, J. 2007. Phytophthora nicotianae: fungicide sensitivity, fitness, and molecular markers. Dissertation, Department of Plant Pathology, Physiology, and Weed Science, Virginia Polytechnic Institute and State University, Blacksburg, VA.

25. Hu, J., Hong, C., Stromberg, E. L., and Moorman, G. W. 2010. Mefenoxam sensitivity in Phytophthora cinnamomi isolates. Plant Dis. 94:39-44.

26. Hu, J. H., Hong, C. X., Stromberg, E. L., and Moorman, G. W. 2008. Mefenoxam sensitivity and fitness analysis of Phytophthora nicotianae isolates from nurseries in Virginia, USA. Plant Pathol. 57:728-736.

27. Hulvey, J., Gobena, D., Finley, L., and Lamour, K. 2010. Co-occurrence and genotypic distribution of Phytophthora species recovered from watersheds and plant nurseries of eastern Tennessee. Mycologia 102:1127-1133.

28. Hunger, R. M., Hamm, P. B., Horner, C. E., and Hansen, E. M. 1982. Tolerance of Phytophthora megasperma isolates to metalaxyl. Plant Dis. 66:645649.

29. Hwang, J., and Benson, D. M. 2005. Identification, mefenoxam sensitivity, and compatibility type of Phytophthora spp. attacking floriculture crops in North Carolina. Plant Dis. 89:185-190.

30. Hwang, J., Jeffers, S. N., and Oak, S. W. 2010. Aquatic habitats-a reservoir for population diversity in the genus Phytophthora (Abstr.). Phytopathology 100:S150.

31. Jerardo, A. 2007. Floriculture and nursery crops yearbook. Econ. Res. Serv. U. S. Dep. Agric. FLO-2007.

32. Lamour, K. H., Daughtrey, M. L., Benson, D. M., Hwang, J., and Hausbeck, 
M. K. 2003. Etiology of Phytophthora drechsleri and P. nicotianae (=P. parasitica) diseases affecting floriculture crops. Plant Dis. 87:854-858.

33. Lamour, K. H., and Hausbeck, M. K. 2000. Mefenoxam insensitivity and the sexual stage of Phytophthora capsici in Michigan cucurbit fields. Phytopathology 90:396-400.

34. Lamour, K. H., and Hausbeck, M. K. 2001. The dynamics of mefenoxam insensitivity in a recombining population of Phytophthora capsici characterized with amplified fragment length polymorphism markers. Phytopathology 91:553-557.

35. Lamour, K. H., and Hausbeck, M. K. 2003. Susceptibility of mefenoxamtreated cucurbits to isolates of Phytophthora capsici sensitive and insensitive to mefenoxam. Plant Dis. 87:920-922.

36. Olson, H. A. 2010. Identification and characterization of species of Phytophthora on ornamental crops of North Carolina commercial greenhouses. Dissertation, Department of Plant Pathology, North Carolina State University, Raleigh, NC.

37. Olson, H. A., and Benson, D. M. 2011. Characterization of Phytophthora spp. on floriculture crops in North Carolina. Plant Dis. 95:1013-1020.

38. Parker, T. Agriculture state fact sheet: Georgia. Economic Research Service, USDA. Retrieved 29 February 2012 from http://www.ers.usda.gov/ StateFacts/GA.HTM

39. Parker, T. Agriculture state fact sheet: North Carolina. Economic Research Service, USDA. Retrieved 29 February 2012 from http://www.ers.usda.gov/ StateFacts/NC.HTM

40. Parker, T. Agriculture state fact sheet: South Carolina. Economic Research Service, USDA. Retrieved 29 February 2012 from http://www.ers.usda.gov/ StateFacts/SC.HTM

41. Parker, T. Agriculture state fact sheet: Tennessee. Economic Research Service, USDA. Retrieved 29 February 2012 from http://www.ers.usda.gov/ StateFacts/TN.HTM

42. Parker, T. Agriculture state fact sheet: Texas. Economic Research Service,
USDA. Retrieved 29 February 2012 from http://www.ers.usda.gov/ StateFacts/TX.HTM

43. Parker, T. Agriculture state fact sheet: Virginia. Economic Research Service, USDA. Retrieved 29 February 2012 from http://www.ers.usda.gov/ StateFacts/VA.HTM

44. Reeser, P. W., Sutton, W., Hansen, E. M., Remigi, P., and Adams, G. C. 2011. Phytophthora species in forest streams in Oregon and Alaska. Mycologia 103:22-35.

45. Robayo-Camacho, E., Hwang, J., and Jeffers, S. N. 2009. A diversity of species of Phytophthora found on floriculture crops (Abstr.). Phytopathology 99:S109.

46. Schoenbaum, E. A. 2008. Genotypic characterization of Phytophthor cinnamomi from ornamental crops in North Carolina Thesis, Plant Pathology, North Carolina State University, Raleigh, NC.

47. Schwingle, B. W., Smith, J. A., and Blanchette, R. A. 2007. Phytophthora species associated with diseased woody ornamentals in Minnesota nurseries. Plant Dis. 91:97-102.

48. Stack, J. P., and Millar, R. L. 1985. Isolation and characterization of a metalaxyl-insensitive isolate of Phytophthora megasperma f. sp. medicaginis Phytopathology 75:1387-1392.

49. Syngenta Crop Protection. 2005. ENVIROfacts: Mefenoxam. Online publication. http://www.syngentacropprotection.com/env_stewardship/futuretopics/ Mefenoxam 12_16_05.pdf

50. USDA. 2007. Agricultural chemical usage. Natl. Agric. Stat. Serv. Ag Ch 1 (07).

51. Warfield, C. Y., Hwang, J., and Benson, D. M. 2008. Phytophthora blight and dieback in North Carolina nurseries during a 2003 survey. Plant Dis. 92:474-481.

52. Yakabe, L. E., Blomquist, C. L., Thomas, S. L., and MacDonald, J. D. 2009. Identification and frequency of Phytophthora species associated with foliar diseases in California ornamental nurseries. Plant Dis. 93:883-890. 